\title{
INKLUZYWNA EDUKACJA RELIGIJNA NA PRZYKŁADZIE SYSTEMU SZKOLNICTWA W NIEMCZECH
}

\begin{abstract}
Streszczenie: W artykule zostają przedstawione główne założenia inkluzywnej edukacji religijnej w niemieckim systemie szkolnictwa. Heterogeniczność kulturowa i etniczna współczesnych społeczeństw europejskich stanowi ważne wyzwanie dla systemu edukacji. Dotyczy to również nauczania religii w warunkach pluralizmu religijno-światopoglądowego. W Niemczech nauczanie tego przedmiotu cechuje duża różnorodność podejść i koncepcji, uzasadniona sytuacją religijnego i kulturowego pluralizmu. Rezultatem tego jest dynamiczny rozwój pedagogiki religii jako dziedziny wiedzy odrębnej od katechetyki. Autorka przedstawia najnowsze koncepcje szkolnego nauczania religii w Niemczech. Stanowią one próbę zdefiniowania na nowo celów i metod nauczania religii w taki sposób, aby w większym niż dotychczas stopniu odpowiadało ono wymogom współczesności.
\end{abstract}

Słowa kluczowe: pedagogika religii; katechetyka; edukacja inkluzywna; pluralizm religijny.

Pluralizacja życia społecznego stanowi jeden z najbardziej widocznych skutków procesu modernizacji w Europie. Różnice kulturowe, etniczne czy religijne stają się stałym elementem społecznego krajobrazu, coraz częściej podkreśla się ich rozwojowy potencjał i związane z nimi szanse. Jednak wzrastająca heterogeniczność współczesnych społeczeństw stanowi również poważne wyzwanie, z którym muszą zmierzyć się instytucje demokratycznego państwa, w tym również placówki edukacyjne. Pojawiają się pytania o to, jak należałoby sformułować cele kształcenia i jakie zastosować metody, aby przygotować dzieci i młodzież do kształtowania życia społecznego w duchu tolerancji i do budowania porozumienia ponad różnicami społecznymi, kulturowymi czy religijnymi.

Nauczanie religii w sytuacji społecznego pluralizmu musi uwzględniać nie tylko różnorodność tradycji religijnych i wyznaniowych w Europie, lecz także najprzeróżniejsze istniejące w ich obrębie dawne i nowe formy religijności, często o charakterze synkretycznym. Złożoność sytuacji potęguje tendencja do rozluźniania więzi z instytucjonalnymi formami religii i wzrost liczby osób, które deklarują się jako bezwyznaniowe. We współczesnym społeczeństwie żyją obok siebie osoby religijne 
i niereligijne, uduchowione i religijnie obojętne, religijni fundamentaliści i ateiści. Istnieją wciąż jeszcze regiony względnie jednolite pod względem wyznaniowym, ale nader często jest to tylko pozorne wrażenie, odnosi się bowiem bardziej do sfery deklaratywnej niż do rzeczywistej sytuacji. Poza tym nawet tam, gdzie przeważają wyznawcy określonej religii, są oni konfrontowani z sytuacją pluralizmu religijnego za pośrednictwem mediów i innych form komunikacji.

Z punktu widzenia tradycyjnych, zinstytucjonalizowanych form religii taka sytuacja jest problematyczna. Postsynodalna adhortacja apostolska Ecclesia in Europa mówi o tym, że Europa przeżywa „okres zagubienia”, którego wyrazem jest „swego rodzaju praktyczny agnostycyzm i obojętność religijna, wywołująca u wielu Europejczyków wrażenie, że żyją bez duchowego zaplecza [...] w wielu sferach publicznych łatwiej jest deklarować się jako agnostycy, niż jako wierzący; odnosi się wrażenie, że niewiara jest czymś naturalnym, podczas gdy wiara wymaga uwierzytelnienia społecznego, które nie jest ani oczywiste, ani przewidywalne" (Jan Paweł II 2003, nr 7). Nie ulega wątpliwości, że socjalizacja religijna jest trudniejszym zadaniem w społeczeństwie pluralistycznym niż monokulturowym, w którym wpływy socjalizacyjne obejmowały praktycznie całe otoczenie społeczne jednostki. Zmiana sytuacji wymusza zmianę założeń i form religijnej socjalizacji, której ważnym składnikiem jest edukacja religijna.

Nauczanie religii w edukacyjnych placówkach niemieckich cechuje duża różnorodność podejść i koncepcji, uzasadniona sytuacją religijnego i kulturowego pluralizmu. Od wielu lat toczą się tam ożywione dyskusje na temat form i metod nauczania religii, czego rezultatem jest dynamiczny rozwój pedagogiki religii jako dziedziny wiedzy odrębnej od katechetyki. Niniejszy artykuł poświęcony będzie założeniom inkluzywnej edukacji religijnej w niemieckim systemie szkolnictwa.

\section{Nauczanie religii w Niemczech - sytuacja obecna i propozycje zmian}

Nauczanie religii o charakterze konfesyjnym (katecheza wyznaniowa) jest zagwarantowane w konstytucji Republiki Federalnej Niemiec, która stanowi, że „religia w szkołach publicznych, z wyłączeniem szkół bezwyznaniowych, jest obowiązkowym przedmiotem szkolnym [...] nauczanie religii odbywa się w zgodzie z zasadami stanowionymi przez poszczególne wspólnoty religijne" (Ustawa Zasadnicza Republiki Federalnej Niemiec, art. 7.3). W większości niemieckich krajów związkowych konfesyjne lekcje religii należą do obowiązkowego programu szkolnego, głębokie procesy przemian społecznych, związane m.in. z nasileniem się w ciągu ostatnich lat masowych ruchów migracyjnych, sprawiają jednak, że tradycyjnie rozumiane nauczanie konfesyjne nie stanowi adekwatnej odpowiedzi na wyzwania, jakie pojawiają się w związku z sytuacją kulturowego i religijnego pluralizmu.

Przypuszcza się, że w ciągu najbliższej dekady już tylko połowa ludności Niemiec będzie uważać się za chrześcijan. W roku 2010 przynależność do wyznania katolickiego deklarowało 30,2 proc. obywateli Niemiec, do ewangelickiego 29,2 proc., 
30,3 proc. natomiast określało się jako bezwyznaniowi. Pozostałe 10,1 proc. stanowili wyznawcy innych wyznań i religii: prawosławni, muzułmanie, buddyści, wyznawcy hinduizmu, judaizmu i mniejszych wspólnot religijnych. Jest to ogromna różnica w porównaniu z wynikami badań przeprowadzonych w roku 1950, w których katolicką lub ewangelicką przynależność wyznaniową deklarowało prawie 96 proc. obywateli (Pollack, Müller 2013). Trendy globalizacyjne i wzrost ogólnoświatowej mobilności będą prawdopodobnie sprzyjać dalszemu spadkowi liczby chrześcijan w Niemczech, spodziewać się natomiast należy wzrostu liczby wyznawców islamu oraz osób bez przynależności wyznaniowej.

Taka sytuacja sprawia, że od dłuższego czasu rozważa się alternatywy wobec konfesyjnego modelu nauczania religii. Zarówno przedstawiciele Kościołów, jak i pedagodzy oraz katecheci mają świadomość tego, że religia w szkole musi stawić czoła sytuacji przełomowej, i że jej przyszłość zależy w dużej mierze od tego, na ile będzie w stanie poradzić sobie ze zjawiskiem religijnego pluralizmu (Englert 2012). Warto pamiętać, że nawet podczas lekcji religii o charakterze katechezy nauczyciele niezwykle rzadko mają do czynienia z grupami rzeczywiście jednolitymi wyznaniowo. Znacznie częściej są to grupy heterogeniczne, obejmujące zarówno uczniów religijnych, jak i religijnie obojętnych, wierzących na swój własny sposób, kontestujących lub poszukujących, przy czym ich poszukiwania nie zawsze mieszczą się w obrębie chrześcijaństwa. Jest to wyzwaniem dla wielu nauczycieli, którzy zmuszeni są do zajmowania stanowiska wobec odmiennych kulturowo treści, nie zawsze dysponując potrzebnymi do tego kompetencjami. W takiej sytuacji propozycje zmian $\mathrm{w}$ dotychczas dominującym modelu nauczania religii nie robią już wrażenia rewolucyjnych - są raczej artykułowane w nawiązaniu do przemian, które dokonały się już, przynajmniej częściowo, w praktyce pedagogicznej.

\section{Inkluzywna pedagogika religii}

Pojęcie inkluzji stało się popularne w słownictwie pedagogicznym niemieckiego obszaru językowego pod koniec XX wieku i odnosiło się początkowo do potrzeby włączania w szkolny proces kształcenia uczniów z różnymi formami niepełnosprawności. Z czasem zyskało ono szersze znaczenie: zaczęło być odnoszone do wszelkich form odmienności i różnorodności istniejących w społeczeństwie i znajdujących swoje odbicie w procesach edukacyjnych. Przyczyną różnych potrzeb edukacyjnych jest bowiem nie tylko niepełnosprawność, lecz także odmienność religijna, kulturowa, przynależność do różnych warstw i środowisk społecznych, bariery językowe itp.

Koncepcja pedagogiki inkluzywnej stanowi próbę przezwyciężenia społecznych podziałów poprzez zmianę sposobu ich postrzegania. Przez wiele lat w systemie szkolnym dominowało przekonanie, że warunkiem skutecznego kształcenia jest względna jednolitość grupy docelowej. Stąd dzielenie uczniów na grupy o standardowych i szczególnych potrzebach edukacyjnych, a także wyznaczanie różnych 
ścieżek edukacyjnych przeznaczonych dla uczniów bardziej i mniej uzdolnionych (Hauptschule, Realschule, Gymnasium). Tymczasem badania pokazują, że nauka w grupach heterogenicznych jest korzystniejsza dla wszystkich grup uczniów. Koncepcja pedagogiki inkluzywnej stanowi próbę wyeliminowania myślenia w kategoriach dualistycznych (uczeń bardziej zdolny-uczeń mniej zdolny; szkoła publiczna-szkoła specjalna itp.) i dążenia za wszelką cenę do ujednolicania klas szkolnych oraz celów kształcenia. Ponieważ uczniowie w życiu społecznym będą na co dzień stykać się z różnorodnością i odmiennością (etniczną, religijną, kulturową), z ludźmi w różnym wieku, różnej płci, o różnych poglądach, możliwościach intelektualnych i stylach życia, to zasadne jest, aby również w trakcie nauki szkolnej byli oni przyzwyczajani do uznawania i szanowania odmienności w różnych jej przejawach. Grupę docelową i przedmiot oddziaływań pedagogicznych ma zatem stanowić nie jakaś konkretna grupa uczniów, wyodrębniona na podstawie określonych cech, lecz wszyscy uczniowie wraz ze swoimi indywidualnymi potrzebami i oczekiwaniami. Celem tak rozumianego kształcenia nie jest maksymalizacja osiągnięć na poziomie czysto kognitywnym, lecz szerzej rozumiane przygotowanie do życia w społeczeństwie, ze szczególnym naciskiem na budowanie porozumienia i pokoju. Szkoła ma być miejscem otwartym i przyjaznym dla wszystkich, bez względu na warunki fizyczne, zdolności, uwarunkowania emocjonalne, umiejętności językowe, sytuację społeczną, przynależność etniczną czy poglądy religijne.

Koncepcja pedagogiki inkluzywnej znajduje zastosowanie w ramach szkolnego nauczania religii. Inkluzywna pedagogika religii uwzględnia fakt, że nauczanie tego przedmiotu dokonuje się w grupach heterogenicznych, a więc np. w grupach uczniów o różnym pochodzeniu kulturowym, żyjących w różnorodnych środowiskach, o różnych światopoglądach i stylach życia, dysponujących odmiennymi wyobrażeniami na temat świata i swojej w nim roli (warto tu zwrócić uwagę np. na różne wyobrażenia kulturowe dotyczące ról płciowych). W takiej sytuacji za cel należy uznać nauczanie odbywające się wprawdzie w ramach jednolitego dla wszystkich programu, ale jednocześnie mocno zindywidualizowane, stwarzające uczniom możliwość włączenia w proces kształcenia własnych talentów i zasobów. Taka koncepcja nie wyklucza konfesyjnego nauczania religii, sprawia jednak, że musi ono w większym niż dotychczas stopniu uwzględniać konieczność współpracy międzyreligijnej i międzywyznaniowej.

Hans-Jörgen Röhrig (brw.) formułuje następująco założenia inkluzywnej pedagogiki religii: ma ona charakter inkluzywny wówczas, gdy z założenia ukierunkowane jest na grupę heterogeniczną, w której poszczególni uczniowie mogą wnieść swój indywidualny wkład w proces kształcenia zależnie od swoich różnorodnych kompetencji; gdy przebiega w duchu dialogu i współpracy; gdy w elastyczny sposób stosowane są różne metody dydaktyczne i formy organizacyjne tak, aby dostosować się do potrzeb wszystkich uczniów; gdy tematyka nauczania prezentowana jest z uwzględnieniem różnych perspektyw i różnych możliwości intelektualnych; gdy akceptuje się to, że uczniowie mogą dążyć do różnych celów i je osiągać. 
Zasady te zostały rozwinięte $\mathrm{w}$ ramach projektu Inreb (inklusive Religionslehrerbildung - inkluzywne kształcenie nauczycieli religii). W 2014 roku grupa pedagogów religii opublikowała Dziesięć zasad inkluzywnego nauczania religii (Berger i in. 2014) odnoszących się do kultury, struktury oraz praktyki nauczania.

W dużym skrócie na zasady te składa się:

- postrzeganie istniejących różnic jako zjawiska pozytywnego i zauważanie wynikających z tego możliwości. Zgodnie z tą zasadą nauczyciele religii powinni wykazywać się wrażliwością na różne formy odmienności oraz dostosowywać do nich przekazywane treści. Uczniów należy zachęcać do wyrażania własnych poglądów oraz akceptowania odmienności przekonań innych. Ważne jest dostrzeganie różnorodnych kompetencji uczniów oraz umiejętne włączenie ich w proces kształcenia;

- odnoszenie się do siebie nawzajem z szacunkiem. Chodzi tu o wykształcenie postawy uważności i poszanowania w odniesieniu do światopoglądów, wierzeń i praktyk religijnych innych uczniów. Nauczyciel powinien dostrzegać pojawiające się konflikty i uczyć uczniów, jak mają je rozwiązywać bez uciekania się do przemocy, poniżania czy dyskryminacji. Uczniowie powinni uzgadniać między sobą reguły zachowania i dyskusji oraz konsekwentnie ich przestrzegać;

- dostrzeganie i usuwanie barier utrudniających uczestnictwo w zajęciach. Wszyscy uczniowie, niezależnie od swoich możliwości, powinni mieć szansę na aktywne uczestniczenie w lekcjach religii. Pomóc mają w tym działania sprzyjające budowaniu pozytywnych relacji między uczniami, a także różne formy pomocy w nauce tym, którzy z różnych przyczyn (np. biograficznych, kulturowych, intelektualnych, emocjonalnych) mają problem ze zrozumieniem prezentowanych treści;

- uwzględnianie różnych interesów i potrzeb uczniów. Może to następować poprzez umożliwianie w ramach zajęć różnych form aktywności i przyswajania wiedzy, koncentrowanie się nie tylko na kognitywnych, lecz również emocjonalnych aspektach kształcenia, nakłanianie uczniów do werbalizowania swoich potrzeb i emocji;

- uczenie pomagania innym oraz proszenia o pomoc. Zgodnie z tą zasadą należy dążyć do wykształcenia w uczniach poczucia wspólnoty, w której każdy czuje się odpowiedzialny za innych, wspiera ich wedle swoich możliwości, współpracuje w planowaniu zajęć i przygotowaniach do nich;

- dialog jako podstawa inkluzywnego nauczania religii. Uczniowie uczą się reguł konstruktywnego prowadzenia dialogu, wyrażania własnych poglądów na tematy egzystencjalne lub religijne, zgłaszania sprzeciwu. Tematyka zajęć powinna być prezentowana $\mathrm{z}$ uwzględnieniem różnych perspektyw i różnych dróg poszukiwania Boga;

- różnicowanie oferty nauczania w celu dostosowania jej do indywidualnych potrzeb i możliwości uczniów. Chodzi tu o włączanie nowo prezentowanych 
treści w istniejące już struktury wiedzy, dostosowanie stopnia trudności zadań do możliwości uczniów, stosowanie metod aktywizujących różne zmysły. Uczniowie powinni być w stanie ocenić własne postępy w nauce i dokumentować je np. w formie portfolio;

- umożliwianie pracy nad tą samą tematyką uczniom o różnych kompetencjach i możliwościach intelektualnych. Może się to dokonywać poprzez przydzielanie uczniom różnych zadań dostosowanych do ich poziomu wiedzy oraz wspieranie i nagradzanie ich osiągnięć tak, aby każdy, niezależnie od poziomu wyjściowego, mógł poszerzać swoje religijne umiejętności;

- ocenianie uczniów w sposób dowartościowujący i motywujący. Nauczyciel powinien stosować różne metody oceniania, aby budować w uczniach dumę z własnych osiągnięć i motywować ich do dalszego poszerzania wiedzy i zdobywania nowych kompetencji;

- włączanie do nauczania religii ogólnych zasad inkluzywnej dydaktyki. W odniesieniu do specyfiki przedmiotu chodzi tu głównie o uwzględnianie odmiennych tradycji religijnych, wspieranie dialogu między wyznaniami, religiami i światopoglądami, traktowanie z powagą indywidualnych poszukiwań uczniów w sferze religijno-duchowej, ich wyobrażeń na temat Boga i spraw ostatecznych. W praktyce może to następować np. poprzez pracę z różnymi tłumaczeniami Biblii oraz uwzględnianie świętych tekstów $\mathrm{z}$ innych religii, odnoszących się do aktualnie omawianej problematyki.

\section{Inkluzywny charakter nowych modeli nauczania religii}

Chociaż postulat inkluzywności stał się ważnym elementem teorii pedagogicznej stosunkowo od niedawna, to warto zauważyć, że wszystkie opracowywane w ostatnich kilkudziesięciu latach w Niemczech programy edukacji religijnej uwzględniały go w większym lub mniejszym stopniu. Dotyczy to np. koncepcji nauczania religii o profilu chrześcijańsko-ekumenicznym, multi- lub interreligijnym lub wyłącznie religioznawczym. W poszczególnych krajach związkowych wypróbowywane były już modele nauczania konfesyjno-kooperatywnego; modułu lekcji religii w perspektywie interreligijnej; lekcji religii dla wszystkich pod patronatem ewangelickim; wprowadzono np. przedmioty nauczania pod nazwą „Sztuka życia etyka - religioznawstwo” czy „Historia biblijna w perspektywie ogólnochrześcijańskiej”. Cechą wymienionych koncepcji była akceptacja różnorodności kulturowej i religijnej prowadząca do przedstawiania jej nie w kategoriach zagrożenia, lecz szansy, a także postawa otwartości na innych, również tych, którzy wydają się obcy. Badania empiryczne pokazały, że młodzież szkolna interesuje się informacjami umożliwiającymi poznanie różnych światowych religii, i jest to jeden z głównych argumentów przeciwko likwidacji lekcji religii w szkole (Mette 2012). Podkreślano ponadto, że refleksja teologiczna i filozoficzna stanowi jeden z wielu sposobów 
poznawania świata, który powinien być przybliżany wszystkim uczniom, nie tylko tym uczącym się w kościelnych placówkach szkolnych.

Postulat inkluzywności jest również ważnym elementem nowszych kierunków rozwojowych współczesnej pedagogiki religii: wychowania do duchowości oraz wychowania do religijnej wrażliwości. U podstaw koncepcji wychowania do duchowości leży przekonanie, że każdy człowiek posiada predyspozycje do przeżyć natury duchowej, choć nie każdy musi identyfikować się z konkretną religią. Przeżycia takie uzdalniają osobę, której udziałem się stają, do wychodzenia poza swoje ograniczenia i otwierania się na innych (Joas 2004). Wychowanie do duchowości jest więc rozwijaniem i podtrzymywaniem drzemiącego w każdym człowieku potencjału, przy czym duchowość rozumiana jest nie jako religia czy mistyka, lecz jako więź człowieka z innymi ludźmi, z naturą, z samym sobą lub z Bogiem (Bucher 2007). Wychowanie do religijnej wrażliwości ma $z$ kolei na celu uwrażliwianie uczniów na religijny wymiar rzeczywistości, jednak bez socjalizacji do konkretnej wspólnoty religijnej. Chodzi tu o wykształcenie umiejętności wyrabiania w sobie poglądów na tematy religijne, przy jednoczesnym zachowywaniu postawy szacunku wobec odmiennych przekonań. W zamierzeniu twórców koncepcji takie kształcenie ma prowadzić do podjęcia świadomej decyzji o przyjęciu lub odrzuceniu światopoglądu religijnego.

Wśród najnowszych koncepcji religijno-pedagogicznych poczesne miejsce zajmuje wciąż koncepcja edukacji religijno-konfesyjnej, która jednak dość istotnie różni się od tradycyjnych podejść katechetycznych. Jej bazę stanowią określone wierzenia i przekonania religijne, jednak nie ma tu elementów indoktrynacji ani wymagań dotyczących znajomości konkretnych czynności rytualnych. Przekaz wiary nie następuje w sposób teoretyczny, lecz pozostaje w ścisłym związku ze światem codziennych doświadczeń uczniów, z ich biografią. Doświadczenia wychowanków są odnoszone do doświadczeń ludzi opisywanych w świętych pismach, przez co otwiera się przestrzeń do ich interpretacji w świetle wiary. Uczniowie otrzymują w ten sposób komunikat, że religie nie są oddzieloną od codziennego życia, osobną sferą, lecz stanowią rezerwuar znaczeń pomocnych w rozumieniu świata i interpretacji własnych przeżyć, szczególnie tych o charakterze egzystencjalnym. Nieodłącznym elementem tak rozumianego kształcenia religijnego jest uwrażliwianie na różnorodność, na istnienie różnych punktów widzenia i systemów wartości. Poczucie więzi z własną wspólnotą religijną nie powinno mieć charakteru ekskluzywnego, lecz łączyć się z otwartością na to, co odmienne i z akceptacją inności. W ten sposób nowy model edukacji konfesyjnej może stać się punktem wyjścia dla kształcenia międzykulturowego i międzyreligijnego (Mette 2014).

Za motywy przewodnie przewijającymi się przez inkluzywne koncepcje nauczania religii w pluralistycznym społeczeństwie uznać należy pojęcia interreligijności, tolerancji oraz relacji. Pierwsze z tych pojęć nie musi bynajmniej oznaczać swobodnego żonglowania treściami zawartymi w różnych religiach, ani też obiektywnego zapoznawania uczniów $\mathrm{z}$ różnymi tradycjami religijnymi bez przyznawania 
którejkolwiek z nich prymatu nad pozostałymi. Chodzi tu raczej o przemyślaną koncepcję, w której uczeń poznaje zasady własnej religii, jednocześnie ucząc się zrozumienia dla innych światopoglądów. Reinhold Boschki (2011, s. 12) zauważa, że zasada ta powinna dotyczyć każdej formy nauczania religii, zarówno tej konfesyjnej, jak i rozumianej bardziej ogólnie: „Zadaniem edukacji religijnej i katechezy stało się nie tylko wprowadzanie w podstawy i praktykę własnej wiary, lecz również dostrzeganie i poznawanie innych dróg religijnych. Ten, komu zależy na religijnym kształceniu i wychowaniu, musi w dzisiejszych czasach uwzględniać również wymiar interreligijny".

Drugie z wymienionych kluczowych pojęć - „tolerancja” - nie oznacza tolerancji biernej, polegającej jedynie na akceptowaniu istnienia różnorodności, bez jakiegokolwiek angażowania się po stronie tych, którzy żyją i wierzą w odmienny sposób. Chodzi tu raczej o tolerancję czynną, tolerancję „bez obojętności” (Gellner, Langenhorst 2013, s. 9), którą cechuje nieustająca gotowość do dialogu i spotkania, dostrzeganie i szanowanie różnic, ciekawość i chęć poznania tego, co odmienne, umiejętność zrozumienia innych perspektyw postrzegania i wyjaśniania świata. Taka czynna tolerancja, zdaniem wielu pedagogów religii, powinna cechować również konfesyjne placówki edukacyjne. Chociaż duże znaczenie w ramach ich koncepcji wychowawczej mają ekskluzywne tradycje religijne, to nie powinny one prowadzić do wykluczania tych, którzy mają odmienne światopoglądy, gdyż znacznie ważniejsze jest akcentowanie wspólnych cech przekonań religijnych.

Taka całościowo pojmowana pedagogika religii akcentuje szczególnie pojęcie relacji (Boschki 2003; Spiegel 1997). Edukacja religijna powinna uwzględniać pięć wymiarów relacji: relację z samym sobą, z innymi, z przyrodą, historią i kulturą, $\mathrm{z}$ czasem oraz z Bogiem. Ważne jest więc, po pierwsze, rozumienie form odnoszenia się do samego siebie w różnych religiach i systemach filozoficznych, a więc działań takich jak modlitwa, medytacja czy autorefleksja. Po drugie, uwzględnianie edukacji społecznej rozumianej jako rozwijanie umiejętności kształtowania relacji międzyludzkich zgodnie z zasadami religii (szacunku, uważności, uprzejmości, miłości bliźniego). Po trzecie, przeżywanie własnej wiary w kontekście jej historii i tła kulturowego, które może stać się bazą do kształtowania własnej tożsamości. Po czwarte, uwzględnianie czasowego wymiaru relacji z innymi, w tym również doświadczeń przemijania, straty lub śmierci. Po piąte, rozwijanie relacji z Bogiem, która jest podstawą wszystkich innych relacji (Boschki 2004).

\section{Wnioski końcowe}

Zasada inkluzywności, stanowiąca podstawę wszystkich nowszych koncepcji szkolnego nauczania religii w Niemczech, jest wyrazem przystosowania systemu edukacyjnego do sytuacji społecznego pluralizmu i zmieniających się potrzeb uczniów, którzy na co dzień stykają się z ogromną różnorodnością światopoglądów, postaw i stylów życia. Jeśli porównać sytuację pedagogiki religii w Niemczech z tą w Polsce, 
na pierwszy rzut oka może ona wydawać się zupełnie odmienna: większość polskich uczniów, przynajmniej formalnie, jest wyznania rzymskokatolickiego, stąd też nauczanie religii ma wciąż w przeważającej części charakter tradycyjno-konfesyjny. Jednak analiza wyników badań religijno-socjologicznych wskazuje na to, iż procesy sekularyzacji i pluralizacji nasilają się też w Polsce, a uczniowie nie stanowią już homogenicznego zbioru osób o podobnych przekonaniach i poglądach. Można więc przypuszczać, że formuła nauczania religii rozumianego jako katecheza, czyli „Kościół w szkole” na dłuższą metę okaże się nieskuteczna. Potrzebna jest refleksja pedagogiczna zmierzająca do nadania lekcjom religii charakteru bardziej niż dotychczas inkluzywnego, otwartego na dialog oraz różnorodność poglądów i przekonań. Religia w szkole może nadal pełnić rolę orientacyjną i sensotwórczą, może nawet bardziej istotną dziś niż kiedykolwiek wcześniej. Aby jednak była w stanie tę funkcję spełnić, trzeba na nowo zdefiniować jej cele i metody, dostosowując je do wymogów współczesności.

\section{Bibliografia}

Berger A. i in. (2014). Zehn Grundsätze für inklusiven Religionsunterricht, dostępny na: https://comenius.de/themen/Inklusion/Zehn_Grundsaetze_fuer_inklusiven_Religionsunterricht_2014.pdf (otwarto: 3.11.2017).

Boschki R. (2003). „Beziehung” als Leitbegriff der Religionspädagogik. Grundlegung einer dialogisch-kreativen Religionsdidaktik, Ostfildern: Schwabenverlag.

Boschki R. (2004). Beziehung - Grundprinzip religiöser Bildung. „Katechetische Blätter”, nr 129, s. 140-148.

Boschki R. (2011). Die spirituelle Dimension interkultureller und interreligiöser Bildung: Chancen einer ganzheitlich-sinnorientierten Pädagogik. W: Kett F. (red.). Jahrbuch 2011. Ganzheitlich-sinnorientiert erziehen und bilden. Ein reformpädagogischer Ansatz auf der Basis eines christlichen Menschenbildes. Gröbenzell: Franz Kett-Verlag, s. 6-13.

Bucher A. (2007). Wurzeln und Flügel. Wie spirituelle Erziehung für das Leben stärkt. Düsseldorf: Patmos.

Englert R. (2012). Religionsdidaktik wohin? - Versuch einer Bilanz. W: Grümme B., Lenhard H., Pirner M. L. (red.). Religionsunterricht neu denken. Innovative Ansätze und Perspektiven der Religionsdidaktik. Ein Arbeitsbuch. Stuttgart: Kohlhammer, s. 247-258.

Gellner Ch., Langenhorst G. (2013). Blickwinkel öffnen. Interreligiöses Lernen mit literarischen Texten. Ostfildern: Matthias-Grünewald Verlag.

Jan Paweł II. (2003). Ecclesia in Europa, dostępny na: https://opoka.org.pl/ biblioteka/W/WP/jan_pawel_ii/adhortacje/europa_28062003.html (otwarto: 20.11.2017).

Joas H. (2004). Braucht der Mensch Religion? Über Erfahrungen der Selbsttranszendenz. Freiburg i.Br.: Verlag Herder. 
Mette N. (2012). Theologie als Bezugswissenschaft für denschulischen Religionsunterricht -angefragt. W: Mette N., Sellmann M. (red.). Religionsunterricht als Ort der Theologie. Freiburg i.Br.: Verlag Herder, s. 338-361.

Mette N. (2014). Edukacja religijna w przedszkolu - podstawy teoretyczne izadania. „Keryks”, nr 13, s. 51-70.

Pollack D., Müller O. (2013). Religionsmonitor. Verstehen was verbindet. Religion und Zusammenhalt in Deutschland. Gütersloh: Bertelsmann Stiftung.

Röhrig H.-J. (brw.). Von der integrativen Pädagogikzum inklusiven Religionsunterricht, dostępny na: http://www.ekir.de/pti/Downloads/integrative-paedagogik.pdf (otwarto: 14.11.2017).

Spiegel E. (1997). Beziehungsverhalten und -handeln von Jugendlichen als Manifestationsformen sublimer Religiosität. „Religionspädagogische Beiträge”, nr 39, s. 165-197.

Ustawa Zasadnicza Republiki Federalnej Niemiec, dostępny na: http://www.gesetze-im-internet.de/gg/art_7.html (otwarto: 21.11.2017).

\title{
INCLUSIVE RELIGIOUS EDUCATION ON THE EXAMPLE OF THE EDUCATION SYSTEM IN GERMANY
}

\begin{abstract}
The article presents the main assumptions of inclusive religious education in the German education system. The cultural and ethnic heterogeneity of contemporary European societies is an important challenge for the education system. This also applies to teaching religion in the conditions of religious and ideological pluralism. Teaching religion in Germany is characterized by a large variety of approaches and concepts, justified by the situation of religious and cultural pluralism. It has resulted in the dynamic development of religious pedagogy as a field of knowledge separate from catechetics. The author presents the latest concepts of school religious education in Germany. They are an attempt to redefine the purposes and methods of teaching religion, so that it better meets the requirements of modern times.
\end{abstract}

Keywords: religious education; catechetics; inclusive education; religious pluralism.

Agnieszka Zduniak - doktor habilitowana socjologii, adiunkt w Katedrze Socjologii Uniwersytetu Warmińsko-Mazurskiego w Olsztynie. Ukończyła filologię germańską na Uniwersytecie Gdańskim oraz studia doktoranckie w Instytucie Socjologii Katolickiego Uniwersytetu Lubelskiego Jana Pawła II. Obszar zainteresowań badawczych: socjologia religii, pedagogika religii, socjologia kultury, komunikacja społeczna. Interesuje się związkami między religią a kulturą współczesną, zjawiskami z dziedziny nowej duchowości oraz nowymi formami zachowań zbiorowych, w szczególności zaś procesem eventyzacji współczesnej kultury. Adres korespondencyjny: Uniwersytet Warmińsko-Mazurski w Olsztynie, ul. Michała Oczapowskiego 2, 10-719 Olsztyn. Adres e-mailowy: a.zduniak@op.pl. 